\title{
Marketplace Wisdom And Consumer Experience: Redefining Sustainability
}

\author{
Djavlonbek Kadirov, Richard Varey, University of Waikato
}

\begin{abstract}
The researchers imagine the possibility of a form of marketing that transcends the managerial technology of value delivery for the immediate satisfaction of consumer needs. The concept of marketplace wisdom is outlined as the outcome of a social process of value co-creation. The intention is to understand how consumers learn how and what to consume in the emerging "technologised" "marketspace", and how to realise sustainable consumption that avoids corrosive excess and provides sufficiency in meeting needs and responsible wants.

The authors identify possibilities of impairment and enrichment in marketing. Thus, the potential for marketing system advancement in a set of oppositional characteristics: identity function and philosophy; interactivity (co-operativeness) - transactional technology and relational social process; value creation - delivery and co-creation; and, impact consumerism and sustainability, is stressed. The researchers note the implication of a re-view of the concept of sustainability in the work, and outline a research strategy for investigating a particular 'marketspace' in search of sources of marketplace wisdom.
\end{abstract}

\section{Marketplace Wisdom}

The recent trends - the shift in focus toward the new conceptual paradigms such as relationships marketing, value co-creation and sustainable marketing - seem to underlie a profound, yet wide movement, possibly, the process of an on-going enrichment of an underlying marketing system. The process is hypothesised to be comprehensive, socially interactive, value-laden, and most importantly, wise. The phenomenon under interest is a hypothesised (or a hoped for) advance to the marketing system, which is governed by virtues of a metacognitive marketplace intelligence, or marketplace wisdom, which happens to indicate to the ideal future role of markets and marketing in society. We define marketplace wisdom as a comprehensive, interactive, value-laden and positive form of integrated social intelligence that guides marketplace action to the sustainable future.

The future is not physical, but ethereal. It resides in minds; to be accurate, in interactive social minds. It comes about through social interaction. The importance of thinking in terms of interactive cognitive structures has attracted the attention of many. Wright (2002) stressed "marketplace metacognition" and "marketplace social intelligence" as a future locus of consumer research. His definition of these concepts was:

\footnotetext{
Marketplace metacognition refers to everyday individuals' thinking about market-related thinking. This includes people's beliefs about their own and others' mental states and processes and their beliefs about other people's beliefs on those topics as these beliefs pertain to the specific domain of marketplace cooperation and manipulation. Marketplace social intelligence refers to the cognitive routines and contents dedicated to achieving marketplace efficacy that are accessible to individuals by virtue of functionally specialized evolutionary processes and the development of this functionally specialized expertise over an individual's life span (Wright, 2002, p.677).
}

It is worth noting that Wright is binding together the theory of interactive (social) minds and the concept of place - here, it is the marketplace. The theory of interactive minds emphasises 
interdependence and interplay among individual cognitions in activating and modifying existing cognitive structures as well as forming new ones (Baltes and Staudinger, 1996). The importance of the concept of place within the field of marketing has lengthily been discussed by a volume of essays edited by John Sherry (1998). The phenomenon under scrutiny is an "emplaced consumption", i.e. consumption happening in certain market spaces. Thus, consumption experiences have been enriched by the place dimension. The attempt to give it a time flavour can also be observed in a substantial body of research on retrospective marketing (Brown and Sherry, 2003). Nevertheless, it might also need to be taken forward toward the future.

In Wright's narration quoted above, "everyday" indicates to that the model of marketplace is considered in a discrete point of time, in a kind of snapshot of a current situation. However, extrapolation of these fixed points along the time dimension to eternity would give us the picture of the future. So what is the essence of futuristic comprehension? Once again in Wright (2002), it is about marketplace co-operation (our term is enrichment) and domination (we call this impairment). To act upon it effectively, as he argues, we need to acquire marketplace social intelligence, which is in our words, would be wisdom or wise decision making. Then the phenomenon we are dealing with seems to be marketplace wisdom. In Wright's expression, this would be "accessible to individuals by virtue of functionally specialized evolutionary processes" and "the development of this functionally specialized expertise over an individual's life span" (p.677). The former is the same as the wisdom as personality trait (Ardelt, 2004a; Ardelt, 2004b), while the latter points to the wisdom as expertise (Baltes and Staudinger, 1993; Baltes and Staudinger, 2000).

An impressive number of researchers claim a positive relationship between individual ageing and the level of wisdom (Ardelt, 2004b; Baltes and Staudinger, 2000; Holliday and Chandler, 1986; Staudinger and Baltes, 1996; Staudinger and Pasupathi, 2003). Similarly, does the marketing system get enlightened and wiser by the elapse of time and experience? If ageing and getting wiser travel hand-by-hand, then it would be plausible to expect that the marketing system might acquire more wisdom through its progress along the time dimension. The perspective chosen to deal with the issue represents the macroscopic marketing systems analysis (Sheth et al., 1988). Consequently, anthropomorphism, the attribution of human characteristics to nonhuman structures, i.e. relating wisdom to the marketing system is quite an adequate method under the systems perspective (von Bertalanffy, 1950).

\section{Impairment and Enrichment}

The concept impairment first was used to explain social methods of control used by a privileged few over the general public for the purpose of deliberately destroying their cognitive capacity and ability to think (Lindblom, 1994). Different from the politicophilosophical view of Lindblom, we conceptualise impairment not as an inter-class activity, rather as a social phenomenon that emerges in the process of interaction and relationships. The effect of this misrepresentation, diversion and confusion is a diseased mind that accepts any social aberration to be prudent and beneficial for all (for example, exhortations to "buy more stuff"). Complex and dynamic social reality is often reduced to that of a finite set of attributes to be tackled by seemingly practical, but actually unpractical "how-to" tools. This phenomenon is rooted in larger cultural dysfunctions such as fragmentation, competition, and reactiveness (Kofman and Senge, 1993), limited by narrowly-focused and dogmatic decision making patterns exercised by managers. 
Yet, the marketing system and the underlying concept have not been left undeveloped.

Conception and re-conception continues in both academia and practice. The understanding, comprehending, learning, and experiencing is never static, but dynamic, continuous, and progressive (Dewey, 1954). This process of marketing development, more or less, reflects advancement and enrichment of the concept. This advancement, arguably, could be in the guise of a hope for the future, or a set of expectations that projects into eternity and holds a positive role in achieving the sustainable system of marketing.

\section{Dimensions of Marketing Advancement}

Thus, we identify the potential for marketing system advancement in a set of oppositional characteristics: identity, interactivity, value creation, and impact. Impairment and enrichment may become activated along these dimensions. The dimensions are consistent with Sheth et al. (1988)'s classification of marketing schools of thought. The interactivity dimension is closely related to their interactive and non-interactive dimensions. Value creation and impact dimensions are related to their economic/non-economic dimensions.

The dimension identity is manifest in function and philosophy; interactivity (cooperativeness) is played out in transactional technology and the relational social process. Value creation is realised in delivery and co-creation. Impact is experienced in consumerism and sustainability. More or less, the former characteristics in all dimensions, namely function, transactional technology, value delivery and consumerism are the examples for impairment, whereas the latter concepts - philosophy, the relational social process, value co-creation and sustainability - represent enrichment of the system.

We do not intend to stress inherent positive/negative (or good/bad) aspects of the dimensional characteristics. Our thinking is that some characteristics may well serve the purpose of advancement better than the others, hence the reference to impairment and enrichment. The oppositional characteristics are not conceptualised as inherently good/bad, rather they might have positive/negative affects to the purpose of sustainable advancement. However, any good may contain bad, or bad may become good, so the next step for us would be to check for dialectical interrelationships between the characteristics

\section{Fresh Thinking on Sustainability}

A totally different understanding of sustainability is required for incorporation of the concept into the marketing perspective. Sustainability is widely defined as the ability to "meet the needs of the present without compromising the ability of future generations to meet their needs" (World Commission on Environment and Development Report, 1987, p.43). The different interpretations for this definition are possible. One way, or the presently dominant view, is to see human generations bargaining for the right to use natural resources that may be depletable or renewable. Resources are thought to be static and finite, and the advantage goes to the one who captures more resource (Hart, 1997; Hart and Milstein, 1999).

The other interpretation could be based on the view of an alternative logic that makes a distinction between operand and operant resources (Vargo and Lusch, 2004). Operand resources are those on which an action is performed to create value, while operant resources 
symbolise knowledge, skills, competencies and capabilities by means of which actions are performed on operant resources. This service-centred logic recognises marketing as a social process of mainly dealing with operant resources. Consequently, in this circumstance, sustainability becomes an issue of how operant resources are handled, while not compromising the traditional view of a fair distribution of resources among generations. Coming generations need, and must be endowed with, the just social institutions and systems (which marketing is to be a kind of) as well as knowledge, skills, and competencies that would nurture an ability in them to construct appropriate operant resources to solve their contemporary problems.

The next generations are going to face totally different challenges to those we face, partly as a consequence of the legacy we provide to them. It may even be that they will not need certain natural resources due to technological and other developments. However, they will always be in need of a healthy ability in knowledge and skills to solve the difficulties they face. If social institutions and processes, such as marketing (as a social capital), render the majority of them (humanity) weak, skill-less, impaired, unhealthy, and dependant on a single dominant view of life, then it is not going to help them in spite of a bulk of natural resources inherited.

Marketing, to be capable of producing sustainable well-being for all, needs to be based on cooperation and enrichment rather than domination and impairment. William McInnes (1964) developed a concept of marketing as a process of actualisation of a potential that exists in a market. The market was thought to consist of separation and relationship. When thinking in terms of an exchange being continuous, dialogical, interactional, and relational (Varey, 2001; Varey, 2002), one more element is required in this model; it is the well-known economic concept of externality. Then the market would consist of separation, relationship and externality. An externality refers to unintended effects of marketing activities, be they positive or negative. A burden of actual or perceived exchange externalities mediates the process of actualisation of a market potential. Swaney (1981) argues that the main externality in the market is the impact on culture, community, and people's well-being. This impact was considered to be mainly negative in terms of erosion of traditional community forms. Sustainable marketing, or just marketing (as a positive social process and institution) in the process of actualising market potentials (separations between related partners under the burden of an externality) must minimise the negative externalities and maximise the positive ones. A negative externality may include cherishing (valuing or co-creating) weakness in dealing with partners (citizens) - consumers, customers, suppliers, employees, competitors.

\section{Research strategy}

The objective will be to study the process of marketing system advancement toward the positive future depicted in the case of synchronic integration between the corporate and citizens' views of sustainability and the effect of relevant socio-psychological factors on the process as they are perceived and reported by parties involved in trading interactions (including pre- and post-purchase contexts). The grounded theory analysis and the systems analysis perspectives will be combined to tackle this issue. We examine the implications and prospects for consumer experience in a marketing system that is collaborative with sustainable value creation as the core principle. Such knowledge is creative rather than descriptive and reproductive, and judged by its consequences rather than by its origins. Our constructive intellectualisation will be tested for validity and truth by conducting interpretive fieldwork that attempts to verify the consequences in the experiences of actors in the buyer- 
seller relationships of a high impact consumer goods market (automobiles). The Toyota company, for example, currently speak of regenerative efforts through collaboration with society. What is the substance behind this statement? Is it mere attention-getting rhetoric?

The purpose of the research is to develop an understanding of the interaction and dialogue between company employees and their customers that can possibly create value for sustainable business, and that is, perhaps, not paid the attention deserved. A corporate brand policy is about creating a positive emotional engagement that customers will have toward a brand. This is enhanced by day-to-day interaction for sustainability, which is based on customers' and employees' experiences, in comparison to the monological promotion of an ungrounded home-made recipe. Today's customers are not passive acceptors of a prepackaged value offered by a company. They are active co-constructors of value they want. Customers may have their definition for sustainable consumption, while a business has its view on the process. The meeting point is believed to be in the interaction between them. Interaction will be studied in terms of a concept of co-created value, i.e. it is the ethos, dimensions, and nature of the chain of events that make a marketing process valuable and responsible for both sellers and buyers. Its content will be investigated to determine whether, or not, sustainability issues emerge through interaction. Sustainability implications for brand management will be identified.

We plan to conduct the project in co-operation with managers, front-line staff, and customers of a major consumer goods manufacturer (to be identified at the time of writing). We propose two activities: A) Exploring the consumer perspective: 1) In-depth interviews with consumers who just bought or expressed interest in the brand, or are active participants of a sustainability project; 2) Review of existing market research data and any other recorded (richly descriptive) material on consumer ideas, suggestions, complaints, and problems (for example, the content of customer generated talk online - weblogs). B) Exploring the company perspective: 1) Indepth interviews with marketing managers, brand managers, and front-line staff ; 2) Review of company documentation and 3) Observation of decision-making to determine courses of action, in marketing management meetings.

Our plan is to produce insightful knowledge on the essence, attributes and conditions of sustainability-consistent value (marketplace wisdom) co-constructed in exchange interaction rather then ready-made and delivered to consumers by companies and how sustainable value can be co-created.

The implication of the theory will be potentially substantial to society and public, individual consumers and managers. Society would see benefits in terms of clarification of the principles that elicit more responsible action from its members. The thrust of public policy making would be guided toward those areas of marketplace activity which are possibly effective in the construction of the marketing system that is sustainable. Managers will get a useful description of a positive vision toward which they should (or must) strive. The vision (of the sustainable marketing system) powered by the emancipatory dialogue of all marketplace actors will be in the guise of a hope for the sustainable future (Brown and Maclaran, 1996) that might result from "communicative action" (Habermas, 1996). Knowing that much of the day-to-day managerial action is performed based on heuristics (the rules of thumb), the theory would supply criteria to build such heuristics so they would connect the brand marketing action to the cause for sustainability. Such criteria needs to be based on the principles of marketplace wisdom, a "meta-heuristic" (Baltes and Staudinger, 2000) that guides social minds toward excellence in difficult judgments about sustainable market behaviour. 


\section{References}

Ardelt, M. (2004a). Where can wisdom be found? Human Development 47 (5), 304-307.

---- (2004b). Wisdom as expert knowledge system: A critical review of a contemporary operationalization of an ancient concept. Human Development 47 (5), 257-285.

Baltes, P. B., Staudinger U.M. (1993). The search for a psychology of wisdom. Current Directions in Psychological Science 2 (3), 75-80.

---- Eds. (1996). Interactive Minds: Life-span Perspectives on the Social Foundation of Cognition. Cambridge University Press, New York.

---- (2000). Wisdom: A metaheuristic (pragmatic) to orchestrate mind and virtue toward excellence. American Psychologist 55 (1), 122-36.

Brown, S., Maclaran P. (1996). The future is past: Marketing, apocalypse and the retreat from utopia. In: Brown S., Bell J., Carson D. (Eds.), Marketing Apocalypse: Eschatology, Escapology and the Illusion of the End, Routledge, London, pp. 260-277.

Brown, S., Sherry J.F. Eds. (2003). Time, Space, and the Market: Retroscapes Rising. M.E.Sharpe, New York.

Dewey, J. (1954). Art and Education (3d ed.). Barnes Foundation Press, Merion, PA.

Habermas, J. (1996). Contributions to a Discourse Theory of Law and Democracy. Polity Press, Cambridge.

Hart, S.L. (1997). Beyond greening: Strategies for a sustainable world. Harvard Business Review 75 (1), 66-77.

Hart, S.L., Milstein M.B. (1999). Global sustainability and the creative destruction of industries. Sloan Management Review 41 (1), 23-34.

Holliday, S.G., Chandler M.J. (1986). Wisdom: Explorations in Adult Competence. Karger, Basel.

Kofman, F., Senge P.M. (1993). Communities of commitment: The heart of learning organizations. Organizational Dynamics 22 (2), 4-24.

Lindblom, C.E. (1994). Modes of inquiry. Journal of Public Administration Research and Theory: J-Part 4 (3), 327-41.

McInnes, W. (1964). A conceptual approach to marketing. In Cox R., Alderson W., Shapiro S.J. (Eds.), Theory in Marketing, Richard D. IRWIN, Inc, Homewood, Ill, pp. 51-67

Sherry, J. F. Ed. (1998). Servicescapes: The Concept of Place in Contemporary Markets. NTC Business Books, Lincolnwood, Ill. 
Sheth, J.N., Gardner D.M., Garrett D.E. (1988). Marketing Theory: Evolution and Evaluation. Wiley, New York.

Staudinger, U. M., Baltes P.B. (1996). Interactive minds: A facilitative setting for wisdomrelated performance? Journal of Personality and Social Psychology 71 (4), 746-48.

Staudinger, U.M., Pasupathi M. (2003). Correlates of wisdom-related performance in adolescence and adulthood: Age-graded differences in "paths" toward desirable development. Journal of Research on Adolescence 13 (3), 239-68.

Swaney, J. A. (1981). Externality and community. Journal of Economic Issues 15 (3), 615628.

Varey, R. J. (2001). Marketing Communication: Principles and Practice. Routledge, London.

---- (2002). Relationship Marketing: Dialogue and Networks in the E-Commerce Era. John Wiley \& Sons, Chichester.

Vargo, S.L., Lusch R.F. (2004). Evolving to a new dominant logic for marketing. Journal of Marketing 68 (1), 1-17.

Von Bertalanffy, L. (1950). An outline of general systems theory. British Journal for the Philosophy of Science 1 (2), 134-165.

Wright, P. (2002). Marketplace metacognition and social intelligence. Journal of Consumer Research 28 (4), 677-683.

World Commission on Environment and Development Report (1987). Our Common Future. Oxford University Press, Oxford. 